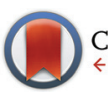

CrossMark \& click for updates

Cite this: Dalton Trans., 2016, 45 11437

Received 29th April 2016, Accepted 9th June 2016

DOI: 10.1039/c6dt01688j

www.rsc.org/dalton

\title{
Lewis acid-base adducts of group 13 elements: synthesis, structure and reactivity toward benzaldehyde $\uparrow$
}

\author{
C. Ganesamoorthy, M. Matthias, D. Bläser, C. Wölper and S. Schulz*
}

\begin{abstract}
Lewis acid-base adducts [ $\left[\mathrm{Ga}-\mathrm{M}\left(\mathrm{C}_{6} \mathrm{~F}_{5}\right)_{3}\right](\mathrm{M}=\mathrm{B} \mathbf{1}, \mathrm{Al} 2, \mathrm{Ga} 3)$ were prepared by the reaction of gallanediyl $L G a\left\{L=H C\left[C(M e) N\left(2,6-i-P_{2} C_{6} H_{3}\right)\right]_{2}\right\}$ with the Lewis acids $M\left(C_{6} F_{5}\right)_{3}(M=B, A l, G a)$. Benzaldehyde reacts with $\left[\mathrm{LGa}-\mathrm{M}\left(\mathrm{C}_{6} \mathrm{~F}_{5}\right)_{3}\right](\mathrm{M}=\mathrm{B} 1, \mathrm{Al} 2)$ at room temperature with the insertion and formation of $\left[\mathrm{LGa}\left(\mathrm{C}_{6} \mathrm{~F}_{5}\right)\right.$ $\left.\left\{\mathrm{CH}(\mathrm{Ph})\left(\mathrm{OB}\left(\mathrm{C}_{6} \mathrm{~F}_{5}\right)_{2}\right)\right\}\right]$ (4) and the zwitterionic species $\left[\mathrm{LGa}\left(\mathrm{C}_{6} \mathrm{~F}_{5}\right)\left\{\mathrm{CH}(\mathrm{Ph})\left(\mathrm{OAl}\left(\mathrm{C}_{6} \mathrm{~F}_{5}\right)_{2}\right)\right\}\right]$ (5), respectively, which was found to decompose at $80{ }^{\circ} \mathrm{C}$ with the formation of $\left\{\left(\mathrm{C}_{6} \mathrm{~F}_{5}\right)_{2} \mathrm{Al}\left(\mathrm{OCCH}_{2} \mathrm{Ph}\right)\right\}_{2}(6)$. Any attempts to isolate the insertion complex of $\left[\mathrm{LGa}-\mathrm{Ga}\left(\mathrm{C}_{6} \mathrm{~F}_{5}\right)_{3}\right]$ with benzaldehyde failed and only $\left\{\left(\mathrm{C}_{6} \mathrm{~F}_{5}\right)_{2} \mathrm{Ga}\left(\mathrm{OCH}_{2} \mathrm{Ph}\right)\right\}_{2}$ (7) was isolated at elevated temperatures. 2-5 and $\mathbf{7}$ were structurally characterized by heteronuclear NMR spectroscopy and single crystal X-ray diffraction.
\end{abstract}

\section{Introduction}

The activation of small molecules including the reversible splitting of $\mathrm{H}_{2}$ by frustrated Lewis pairs (FLP) has received growing interest since the initial report of Stephan et al. in 2006. ${ }^{1}$ Most FLPs contain the strong Lewis acid $\mathrm{B}\left(\mathrm{C}_{6} \mathrm{~F}_{5}\right)_{3}$ and Lewis basic phosphines $\mathrm{PR}_{3}$, but other Lewis acids such $\mathrm{Al}\left(\mathrm{C}_{6} \mathrm{~F}_{5}\right)_{3}{ }^{2}$ and Lewis bases such as $\mathrm{N}$-bases ${ }^{3}$ and singlet carbenes $\mathrm{CR}_{2}{ }^{4}$ have also been successfully applied for the synthesis of FLP. In addition, FLPs containing a constrained geometry with a rigid molecular backbone were initially prepared by Erker et al., ${ }^{5}$ while Uhl et al., Stephan et al. and others expanded this class of compounds to Al/P FLPs. ${ }^{6}$

LGa $\left(\left\{\mathrm{L}=\mathrm{HC}\left[\mathrm{C}(\mathrm{Me}) \mathrm{N}\left(2,6-\mathrm{i}-\mathrm{Pr}_{2} \mathrm{C}_{6} \mathrm{H}_{3}\right)\right]_{2}\right\}\right)$, which is monomeric in the solid state and in solution, ${ }^{7}$ may react as an electrophilic and a nucleophilic reagent due to the presence of an electron lone pair and an empty p-orbital. However, quantum chemical calculations proved that LGa is a good $\sigma$-donor but a poor $\pi$-acceptor. ${ }^{8}$ The excellent $\sigma$-donor capacity of LGa was proven in reactions with Lewis acidic complexes such as $\mathrm{B}\left(\mathrm{C}_{6} \mathrm{~F}_{5}\right)_{3}$, yielding the Lewis acid-base adduct LGa- $\mathrm{B}\left(\mathrm{C}_{6} \mathrm{~F}_{5}\right)_{3},{ }^{9}$ and in reactions with a large variety of $\mathrm{p}$ - and d-block metal complexes. ${ }^{10}$

Institute of Inorganic Chemistry, University of Duisburg-Essen, 45117 Essen, Germany. E-mail: stephan.schulz@uni-due.de; Fax: +49201 1833830; Tel: +492011834635

$\dagger$ Electronic supplementary information (ESI) available: Crystallographic data of 2-5, and 7 and ${ }^{1} \mathrm{H},{ }^{13} \mathrm{C}\left\{{ }^{1} \mathrm{H}\right\}$ and ${ }^{19} \mathrm{~F}$ NMR spectra and IR spectra of 2-7. CCDC 1477155-1477158. For ESI and crystallographic data in CIF or other electronic format see DOI: 10.1039/c6dt01688j
Due to our general interest in Lewis acid-base reactions, ${ }^{11}$ we investigated the reactions of group 13 Lewis acid $\mathrm{MR}_{3}(\mathrm{M}=$ $\mathrm{Al}, \mathrm{Ga}, \mathrm{In})$ and group 15 Lewis bases $\mathrm{ER}_{3}(\mathrm{E}=\mathrm{N}, \mathrm{P}, \mathrm{As}, \mathrm{Sb}, \mathrm{Bi})^{12}$ and $\mathrm{E}_{2} \mathrm{R}_{4}(\mathrm{E}=\mathrm{Sb}, \mathrm{Bi}){ }^{13}$ In addition, these studies were expanded to group 13 diyl compounds $\mathrm{Cp}^{*} \mathrm{M}(\mathrm{M}=\mathrm{Al}, \mathrm{Ga}, \mathrm{In})$, which also serve as Lewis bases due to the presence of an electron lone pair. ${ }^{14}$ More recently, we started to investigate the reactions of LGa with different main group metal compounds including $\mathrm{InEt}_{3},{ }^{15} \mathrm{BiEt}_{3},{ }^{16} \mathrm{Sb}\left(\mathrm{NMe}_{2}\right)_{3},{ }^{17} \mathrm{E}_{2} \mathrm{Et}_{4}(\mathrm{E}=\mathrm{Sb}, \mathrm{Bi})^{18}$ as well as $\mathrm{TeEt}_{2}$ and $\mathrm{Te}_{2} \mathrm{Et}_{2},{ }^{19}$ respectively, in detail. We herein expanded our investigations on the reactions of LGa with different group 13 Lewis acids $\mathrm{M}\left(\mathrm{C}_{6} \mathrm{~F}_{5}\right)_{3}(\mathrm{M}=\mathrm{B}, \mathrm{Al}, \mathrm{Ga})$ and also report on their potential use for small molecule activation reactions such as benzaldehyde.

\section{Results and discussion}

LGa readily reacts at ambient temperature with $\mathrm{M}\left(\mathrm{C}_{6} \mathrm{~F}_{5}\right)_{3}(\mathrm{M}=$ $\mathrm{Al}, \mathrm{Ga})$ to form the Lewis acid-base adducts [LGa-Al $\left(\mathrm{C}_{6} \mathrm{~F}_{5}\right)_{3}$ ] 2 and $\left[\mathrm{LGa}-\mathrm{Ga}\left(\mathrm{C}_{6} \mathrm{~F}_{5}\right)_{3}\right] 3$ in good yields as was previously reported for the reaction of $\mathrm{LGa}$ and $\left.\mathrm{B}_{(} \mathrm{C}_{6} \mathrm{~F}_{5}\right)_{3}$ (Scheme 1). ${ }^{9}$ 2 and 3 are colourless solids, which are moderately stable toward air and can be stored at room temperature under an

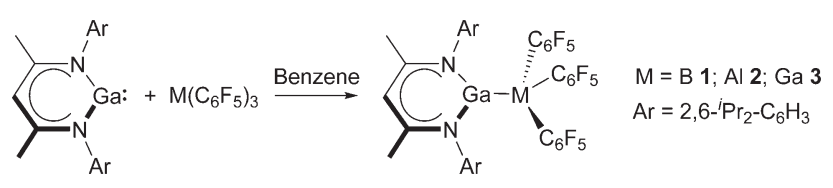

Scheme 1 Synthesis of 1, 2 and 3. 
inert gas atmosphere for several months. ${ }^{1} \mathrm{H},{ }^{13} \mathrm{C}\left\{{ }^{1} \mathrm{H}\right\}$ and ${ }^{19} \mathrm{~F}$ NMR spectra of 1, 2 and $\mathbf{3}$ are almost identical and show the characteristic resonances of the organic substituents. The formation of 2 and 3 was also confirmed by single crystal X-ray diffraction studies. A temperature dependent ${ }^{1} \mathrm{H}$ NMR spectroscopy study with compound 2 was performed (Fig. S26†), clearly demonstrating that the chemical shifts of the gallanediyl fragment LGa in $\mathbf{2}$ are shifted compared to those of pure LGa. According to these findings, we assume that $\mathbf{2}$ is only to a very less extent dissociated in solution at ambient temperature.

Fig. 1 and 2 show the molecular structures of 2 and 3. 2 and 3 are isostructural and crystallize in the monoclinic crystal system in the space group $P 2_{1} / n$. The $\mathrm{Ga}^{\mathrm{I}}$ atom in 1-3 adopts trigonal planar geometries whereas the $\mathrm{M}^{\mathrm{III}}$ atoms of the $\mathrm{M}\left(\mathrm{C}_{6} \mathrm{~F}_{5}\right)_{3}$ unit $(\mathrm{M}=\mathrm{B}, \mathrm{Al}, \mathrm{Ga})$ adopt distorted tetrahedral geometries. The average Ga-N bond lengths in 1 (1.942(6) $\AA$ ), 2 (1.9265 $\AA$ ) and $3(1.9235 \AA)$ are similar and considerably shorter than those observed in LGa (2.054(2) $\AA$ ), which was previously explained by Power et al. by the conversion of the gallium electron lone pair into a gallium-boron donor-acceptor bond, and the concomitant development of positive and negative charges on the gallium and boron atoms. ${ }^{9}$

The $\mathrm{Ga}^{\mathrm{I}}-\mathrm{Al}^{\mathrm{III}}$ bond length of $2(2.5482(4) \AA)$ is in between those reported for $\mathrm{Cp}^{*} \mathrm{Ga}-\mathrm{AlR}_{3}\left\{\mathrm{R}=t\right.$-Bu $(2.629(2) \AA),{ }^{14} \mathrm{C}_{6} \mathrm{~F}_{5}$ $(2.515(11) \AA)\},{ }^{20}$ while the $\mathrm{Ga}^{\mathrm{I}}-\mathrm{Ga}^{\mathrm{III}}$ bond length in $3(2.4819(2)$ $\AA)$ is comparable to those observed in CpGa-GaCp $\mathrm{C}_{2} \mathrm{I}(2.4690$ (17) $\AA),{ }^{21}\left[\mathrm{HB}\left(3,5-\left(\mathrm{CF}_{3}\right)_{2} \mathrm{Pz}\right)_{3}\right] \mathrm{Ga}^{-G} \mathrm{I}_{3}(2.494(2) \AA),{ }^{22}[\mathrm{HB}(3,5-(t-$ $\left.\left.\mathrm{Bu})_{2} \mathrm{Pz}\right)_{3}\right] \mathrm{Ga}^{-\mathrm{GaI}_{3}}(2.506(3) \AA)^{23}$ In contrast, those reported for $\left[\mathrm{Tm}^{t-\mathrm{Bu}}\right] \mathrm{Ga}^{-\mathrm{GaI}_{3}}$ (2.4138(4), 2.4254(3) $\AA$ ); $\left\{\mathrm{Tm}^{t \text {-Bu }}=\operatorname{tris}(2\right.$-mer-

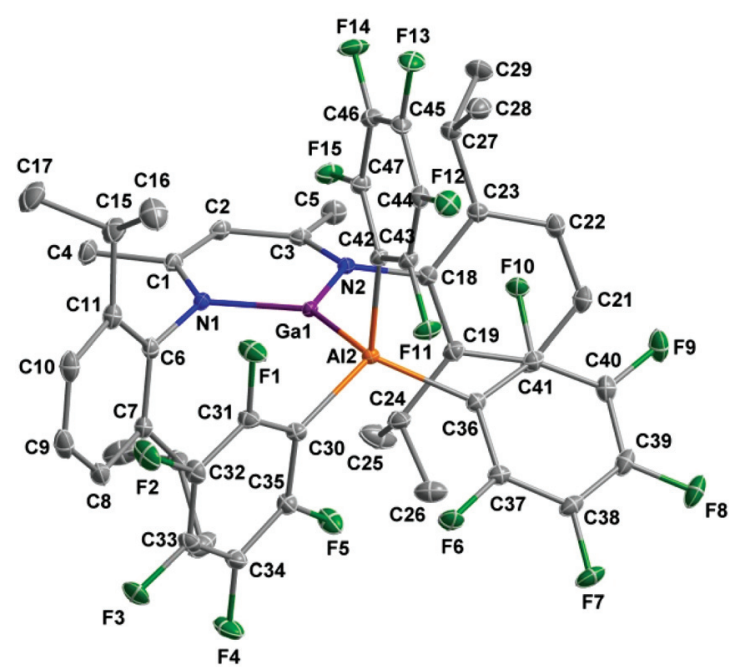

Fig. 1 Solid state structure of 2 (thermal ellipsoids are shown at 30\% probability levels); $\mathrm{H}$ atoms are omitted for clarity. Selected bond lengths and angles in $\AA$ and ${ }^{\circ}: \mathrm{Ga}(1)-\mathrm{Al}(2) 2.5482(4), \mathrm{Ga}(1)-\mathrm{N}(1)$ 1.9265(10), $\mathrm{Ga}(1)-\mathrm{N}(2)$ 1.9261(9), $\mathrm{Al}(2)-\mathrm{C}(30) 2.0007(12), \mathrm{Al}(2)-\mathrm{C}(36) 2.0082(12)$, $\mathrm{Al}(2)-\mathrm{C}(42) \quad 2.0114(11), \quad \mathrm{N}(2)-\mathrm{Ga}(1)-\mathrm{N}(1) \quad 95.35(4), \quad \mathrm{N}(2)-\mathrm{Ga}(1)-\mathrm{Al}(2)$ 136.28(3), $\quad \mathrm{N}(1)-\mathrm{Ga}(1)-\mathrm{Al}(2) \quad 128.27(3), \quad \mathrm{C}(30)-\mathrm{Al}(2)-\mathrm{Ga}(1) \quad 105.99(4)$, $\mathrm{C}(36)-\mathrm{Al}(2)-\mathrm{Ga}(1)$ 113.86(3), C(42)-Al(2)-Ga(1) 102.59(3), C(30)-Al(2)-C(36) 111.51(5), C(30)-Al(2)-C(42) 113.44(5), C(36)-Al(2)-C(42) 109.19(5).

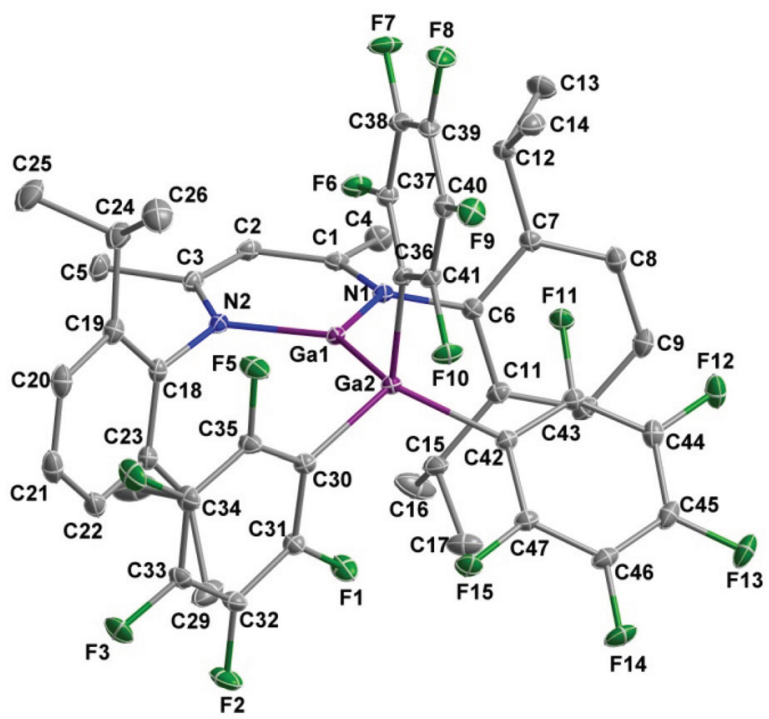

Fig. 2 Solid state structure of 3 (thermal ellipsoids are shown at 30\% probability levels); $\mathrm{H}$ atoms are omitted for clarity. Selected bond lengths and angles in $\AA$ and ${ }^{\circ}: G a(1)-G a(2)$ 2.4819(2), $G a(1)-N(1)$ 1.9233(9), Ga(1)-N(2) 1.9236(9), Ga(2)-C(30) 2.0053(11), Ga(2)-C(36) 2.0127(11), $\mathrm{Ga}(2)-\mathrm{C}(42)$ 2.0154(11), N(1)-Ga(1)-N(2) 96.95(4), N(1)-Ga(1)$\mathrm{Ga}(2)$ 136.39(3), N(2)-Ga(1)-Ga(2) 127.59(3), C(30)-Ga(2)-C(36) 112.89(4), $C(30)-G a(2)-C(42) \quad 111.08(4), C(36)-G a(2)-C(42) \quad 108.04(4), C(30)-$ $\mathrm{Ga}(2)-\mathrm{Ga}(1)$ 107.12(3), C(36)-Ga(2)-Ga(1) 102.94(3), C(42)-Ga(2)-Ga(1) 114.61(3)

capto-1-tert-butylimidazolyl)hydroborate $\},{ }^{24} \quad \mathrm{Cp}^{*} \mathrm{Ga}-\mathrm{Cp}^{*} \mathrm{GaX}_{2}$ $\left\{\mathrm{X}=\mathrm{Cl}, 2.4245(3) ; \mathrm{I}, 2.437(2) \AA{ }^{2}\right\},{ }^{25}\left[\mathrm{HB}\left(3,5-(\mathrm{Me})_{2} \mathrm{Pz}\right)_{3}\right] \mathrm{Ga}^{-\mathrm{GaX}_{3}}$ $\left(\mathrm{X}=\mathrm{Cl}, 2.4155(7) \AA\right.$; I, 2.4215(5) $\AA$ ) and $\left\{\left[\mathrm{HB}\left(3,5-(\mathrm{Me})_{2} \mathrm{Pz}\right)_{3}\right]\right.$ $\mathrm{Ga}_{2}\left[\mathrm{Ga}_{2} \mathrm{I}_{4}\right](2.4358(8) \AA)$ are shorter. ${ }^{26}$ In addition, the $\mathrm{Ga}^{\mathrm{I}}-\mathrm{M}^{\mathrm{III}}$

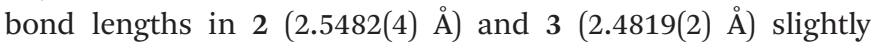
deviate from the sum of the covalent radii (single-bond covalent radii of $\mathrm{Al} 1.26 \AA$, Ga $1.24 \AA$ ). ${ }^{27}$ However, one has to keep in mind that the covalent radii are not really helpful for the discussion of E-E distances due to a strong charge separation, in particular in the case of the organoaluminum compound. As a consequence, the intermetallic bond distances are strongly influenced by electrostatic repulsion between the metal atoms resulting from their relatively high partial positive charges.

In order to investigate the potential use of 1-3 for the activation of small molecules, we investigated exemplarily their reactions with benzaldehyde. The reaction of $\left[\mathrm{LGa}-\mathrm{B}\left(\mathrm{C}_{6} \mathrm{~F}_{5}\right)_{3}\right]$ 1 with an equimolar amount of benzaldehyde occurred with the insertion and subsequent migration of one $\mathrm{C}_{6} \mathrm{~F}_{5}$ moiety, finally resulting in the formation of $\left[\mathrm{LGa}\left(\mathrm{C}_{6} \mathrm{~F}_{5}\right)\{\mathrm{CH}(\mathrm{Ph})(\mathrm{OB}\right.$ $\left.\left.\left.\left(\mathrm{C}_{6} \mathrm{~F}_{5}\right)_{2}\right)\right\}\right] \mathbf{4}$ in high yield (Scheme 2).

The rather complex ${ }^{1} \mathrm{H}$ NMR spectrum shows four septets and eight doublets for the isopropyl substituents. In addition, four singlets for the $\gamma-\mathrm{CH}(5.00 \mathrm{ppm})$, the $\mathrm{CHPh}(5.89 \mathrm{ppm})$ and the $\mathrm{ArNCCH}_{3}$ protons $(1.49,1.33 \mathrm{ppm}$ ) result from the chirality of the $\mathrm{CHPh}$ carbon atom as well as the hindered rotation about the $N$-aryl bonds. The ${ }^{13} \mathrm{C}\left\{{ }^{1} \mathrm{H}\right\}$ NMR spectrum of 4 displays interestingly three $(171.3,171.3,170.9 \mathrm{ppm})$ and two $(100.0,99.9 \mathrm{ppm})$ resonances for the $\mathrm{ArNCCH}_{3}$ and $\gamma-\mathrm{CH}$ 


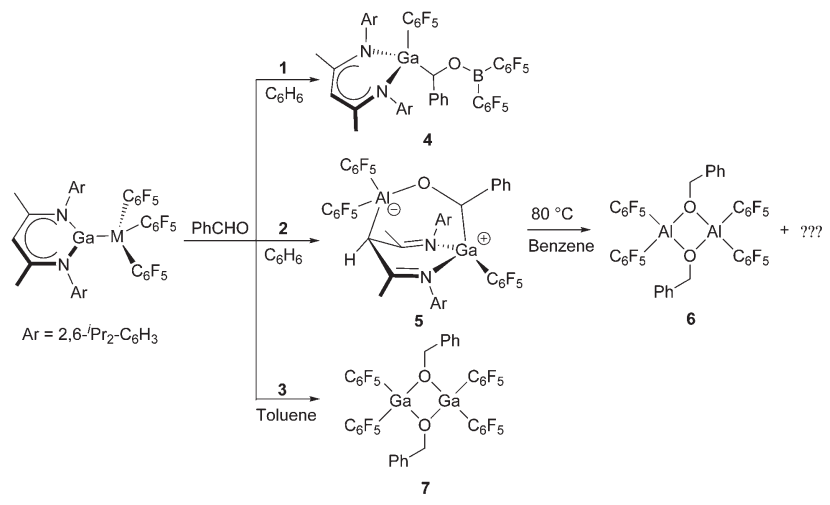

Scheme 2 Reactivity studies of 1-3 with benzaldehyde.

carbon atoms, respectively. Nevertheless, ${ }^{13} \mathrm{C}\left\{{ }^{1} \mathrm{H}\right\}$ and ${ }^{19} \mathrm{~F}$ NMR spectra are consistent with the formation of $\mathbf{4}$. The molecular structure of $\mathbf{4}$ is further elucidated by single crystal X-ray diffraction studies.

Crystals of 4 suitable for a single crystal X-ray diffraction study were obtained from a saturated toluene solution at $-30{ }^{\circ} \mathrm{C}$ after storage for 2 days. 4 crystallises in the monoclinic space group $P 2_{1} / c$. The Ga atom adopts a distorted tetrahedral coordination geometry, whereas the $\mathrm{B}$ atom shows a trigonal planar coordination sphere and the sum of the bond angles is close to $360^{\circ}$. The six-membered $\mathrm{C}_{3} \mathrm{~N}_{2} \mathrm{Ga}$ rings in $\mathrm{LGa}$ and LGa-B $\left(\mathrm{C}_{6} \mathrm{~F}_{5}\right)_{3} \mathbf{1}$ are essentially planar, whereas the Ga atom in 4 is out of plane (deviation from the best plane of the ligand backbone $0.721(4) \AA$ ). The bite angles of the chelating organic ligand $\mathrm{L}\left(96.1(1)^{\circ} 1,95.4(1)^{\circ} 2,96.0(1)^{\circ} 3,96.0(1) 4\right)$ are almost identical. The Ga-N bond lengths in 4 (1.951(3), 1.967(3) Å) are shorter than those in LGa as was observed for 2 and 3.

The analogous reaction of 2 with benzaldehyde afforded the zwitterionic compound, $\left[\mathrm{LGa}\left(\mathrm{C}_{6} \mathrm{~F}_{5}\right)\left\{\mathrm{CH}(\mathrm{Ph})\left(\mathrm{OAl}\left(\mathrm{C}_{6} \mathrm{~F}_{5}\right)_{2}\right)\right\}\right] 5$. The formation of $\mathbf{5}$ most likely occurs with the initial formation of the insertion product as was observed for $\mathbf{4}$, but we were not able to isolate this species. $\mathbf{5}$ is subsequently formed by the rearrangement of the two substituents $\left\{\mathrm{C}_{6} \mathrm{~F}_{5}, \mathrm{CH}(\mathrm{Ph})\right.$ $\left.\left(\mathrm{OAl}\left(\mathrm{C}_{6} \mathrm{~F}_{5}\right)_{2}\right)\right\}$ as shown in Scheme 3a.

This reaction also proves that $\beta$-diketiminate ligands should not be regarded as non-innocent ligands as was previously demonstrated in reactions of cationic $\beta$-diketiminate aluminium complexes of the type $[\mathrm{LAlR}]^{+} \mathrm{B}\left(\mathrm{C}_{6} \mathrm{~F}_{5}\right)_{4}{ }^{-}(\mathrm{R}=\mathrm{Me}$, Et, ${ }^{\mathrm{i}} \mathrm{Bu}$ ), which were found to undergo cycloaddition reactions with alkenes and alkynes with the subsequent formation of similar $\beta$-diketimine complexes of the general type $\left[\kappa_{3}-N, N, \mathrm{C}-\right.$ $\left.\left\{\mathrm{HC}\left(\mathrm{C}(\mathrm{Me}) \mathrm{N}\left(2,6-\mathrm{i}-\mathrm{Pr}_{2} \mathrm{C}_{6} \mathrm{H}_{3}\right)\right)_{2}\left(\mathrm{R}^{\prime} \mathrm{C}=\mathrm{CR}^{\prime \prime}\right)\right\} \mathrm{AlR}\right]^{+}\left[\mathrm{B}\left(\mathrm{C}_{6} \mathrm{~F}_{5}\right)_{4}\right]^{-}\left(\mathrm{R}^{\prime}=\right.$ $\left.\mathrm{R}^{\prime \prime}=\mathrm{Me} ; \mathrm{R}^{\prime}=\mathrm{Ph}, \mathrm{R}^{\prime \prime}=\mathrm{H}\right)$ and $\left[\kappa_{3}-N, N, \mathrm{C}-\{\mathrm{HC}(\mathrm{C}(\mathrm{Me}) \mathrm{N}\right.$ $\left.\left.\left.\left(2,6{ }^{\mathrm{i}}{ }^{\mathrm{P}} \mathrm{Pr}_{2} \mathrm{C}_{6} \mathrm{H}_{3}\right)\right)_{2}\left(\mathrm{R}^{\prime} \mathrm{CHCH}_{2}\right)\right\} \mathrm{AlR}\right]^{+}\left[\mathrm{B}\left(\mathrm{C}_{6} \mathrm{~F}_{5}\right)_{4}\right]^{-}\left(\mathrm{R}^{\prime}=\mathrm{H},{ }^{n} \mathrm{Bu}\right) \cdot{ }^{28}$ In addition, we recently reported on the synthesis of the homoleptic thio- $\beta$-ketimine zinc complex $[\mathrm{MesNC}(\mathrm{Me}) \mathrm{CH}\{\mathrm{C}(\mathrm{Me})$ NMes $\} S]_{2} Z n$ by the reaction of elemental sulfur with $\left[\mathrm{CH}\left\{\mathrm{C}(\mathrm{Me}) \mathrm{NMes}_{2}\right] \mathrm{ZnMe}\left(\mathrm{Mes}=2,4,6-\mathrm{Me}_{3} \mathrm{C}_{6} \mathrm{H}_{2}\right){ }^{29}\right.$

The ${ }^{1} \mathrm{H}$ NMR spectrum of 5 shows four septets $(3.26,2.88$, 2.57, $2.41 \mathrm{ppm})$, three distinct doublets $(1.24,0.98,0.61 \mathrm{ppm})$

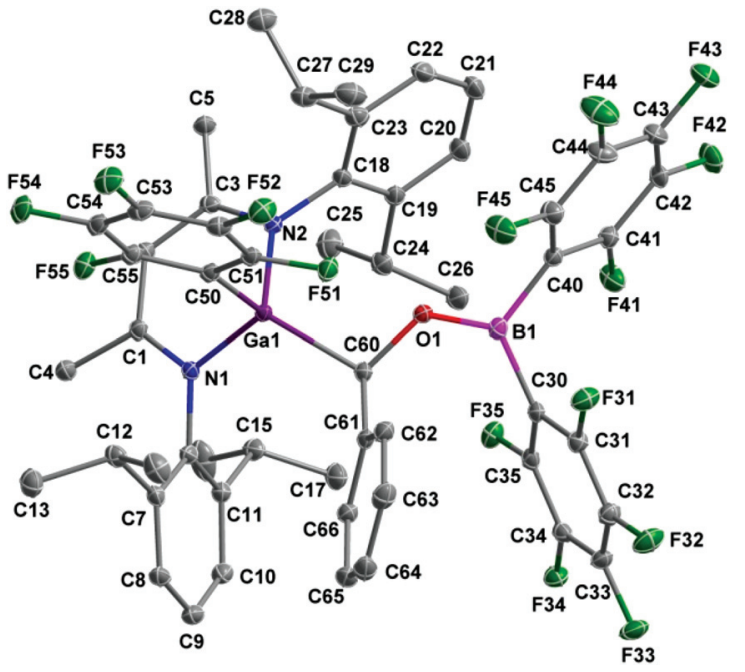

Fig. 3 Solid state structure of 4 (thermal ellipsoids are shown at 30\% probability levels); $\mathrm{H}$ atoms are omitted for clarity. Selected bond lengths and angles in $\AA$ and ${ }^{\circ}: \mathrm{Ga}(1)-\mathrm{N}(1)$ 1.951(3), $\mathrm{Ga}(1)-\mathrm{N}(2)$ 1.967(3), $\mathrm{Ga}(1)-C(60)$ 2.010(3), $G a(1)-C(50) 2.034(3), B(1)-O(1)$ 1.332(4), B(1)$C(40) 1.583(5), B(1)-C(30) 1.589(5), O(1)-C(60) 1.470(4), C(60)-C(61)$ 1.510(4); $\mathrm{N}(1)-\mathrm{Ga}(1)-\mathrm{N}(2)$ 96.0(1), N(1)-Ga(1)-C(60) 109.9(1), N(2)-Ga (1) $-C(60)$ 111.9(1), N(1)-Ga(1)-C(50) 110.2(1), N(2)-Ga(1)-C(50) 106.0(1), $C(60)-G a(1)-C(50) 120.2(2), O(1)-B(1)-C(40) 117.0(3), O(1)-B(1)-C(30)$ 125.1(3), $C(40)-B(1)-C(30)$ 117.9(3), B(1)-O(1)-C(60) 125.0(2), O(1)$C(60)-G a(1) 105.9(2), C(61)-C(60)-G a(1) 117.4(2)$.

and two multiplets at $1.06 \mathrm{ppm}$ (two overlapping doublets) and $0.44 \mathrm{ppm}$ (three overlapping doublets) for the isopropyl substituents as well as the four expected singlets for the $\gamma$-CH (4.71 ppm), $\mathrm{ArNCCH}_{3}(1.55,1.53 \mathrm{ppm})$ and $\mathrm{CHPh}(6.42 \mathrm{ppm})$

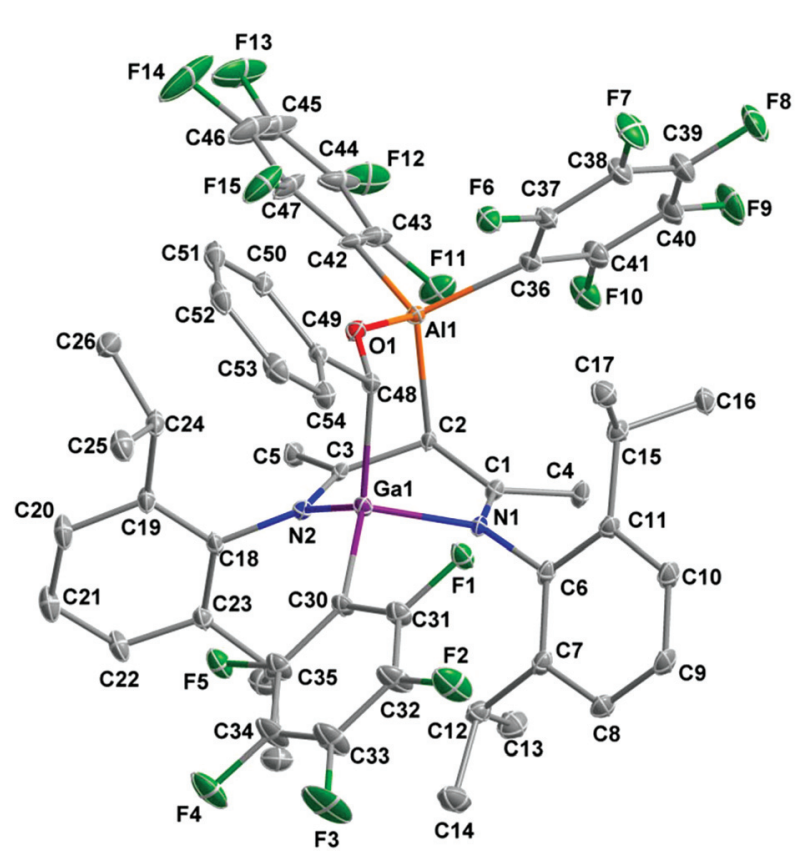

Fig. 4 Solid state structure of 5 (thermal ellipsoids are shown at 30\% probability levels); $\mathrm{H}$ atoms and the lattice solvent are omitted for clarity. 


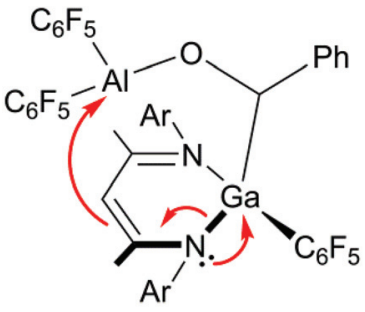

a

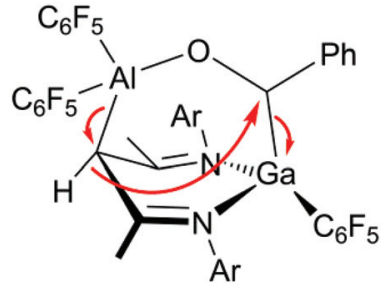

b
Scheme 3 Proposed reaction mechanism for the formation of 5 and 6.

groups. The $\gamma$-CH resonance of 5 (71.1 ppm) in the ${ }^{13} \mathrm{C}\left\{{ }^{1} \mathrm{H}\right\}$ NMR is shifted to a higher field compared to that observed for 2 (102.4 ppm) as was also observed for the imine carbon resonances (170.4 ppm 2, 188.4, 186.6 ppm 5). Such drastic chemical shifts were not observed in the ${ }^{13} \mathrm{C}\left\{{ }^{1} \mathrm{H}\right\}$ NMR spectrum of $\mathbf{4}$ in comparison to $\mathbf{1}$ and the findings are consistent with the conversion of the $\beta$-diketiminate ligand of 2 into a $\beta$-diketimine ligand in 5 (re-hybridization from $\mathrm{sp}^{2}$ to $\mathrm{sp}^{3}$ ). Any attempt to thermally convert $\mathbf{4}$ into a zwitterionic analogue of 5 failed since $\mathbf{4}$ was found to be thermally very stable and could be heated in benzene $\left(80^{\circ} \mathrm{C}\right)$ for several hours without any decomposition. In contrast, compound $\mathbf{5}$ is thermolabile and further decomposes above $40{ }^{\circ} \mathrm{C}$ with the subsequent formation of $\left\{\left(\mathrm{C}_{6} \mathrm{~F}_{5}\right)_{2} \mathrm{Al}\left(\mathrm{OCH}_{2} \mathrm{Ph}\right)\right\}_{2} \mathbf{6}$ as well as so far unidentified products. A possible decomposition pathway is depicted in Scheme $3 b$.

An inspection of the reciprocal lattice of the crystals of 5 suggests a non-merohedral twinning with a pronounced overlap of the reflections. Even after re-collecting data with a reduced scan-width per frame and increased detector distance a separation was not possible. Consequently, the quality of the resulting structure model is limited but still good enough to confirm the connectivity of $\mathbf{5}$.

$\mathbf{4}$ and $\mathbf{5}$ are most likely formed in a two-step reaction process as was shown by in situ ${ }^{1} \mathrm{H}$ NMR spectroscopy studies on the stepwise reactions of benzaldehyde with $\mathrm{B}\left(\mathrm{C}_{6} \mathrm{~F}_{5}\right)_{3}$ and $\mathrm{Al}\left(\mathrm{C}_{6} \mathrm{~F}_{5}\right)_{3}$, which proceeded with the formation of the corresponding Lewis acid-base adducts, which then consequently reacted with LGa with the formation of $\mathbf{4}$ and $\mathbf{5}$, respectively (Fig. S27 and S28†). The experiments clearly demonstrated that the simultaneous presence of both the Lewis acid and the Lewis base, which is the prerequisite for a concerted reaction mechanism as is typical for frustrated Lewis acid-base pairs, is not necessary.

Several attempts to synthesise the $\mathrm{Ga}-\mathrm{Ga}$ analogues of 5 by the reaction of 3 and benzaldehyde failed and only the starting reagents were recovered. However, equimolar amounts of 3 and benzaldehyde reacted in toluene at $120{ }^{\circ} \mathrm{C}$ with the formation of $\left\{\left(\mathrm{C}_{6} \mathrm{~F}_{5}\right)_{2} \mathrm{Ga}\left(\mathrm{OCH}_{2} \mathrm{Ph}\right)\right\}_{2} 7$ in $18 \%$ yield. 6 and 7 are moderately stable towards air. They dissolve well upon heating in benzene, toluene and chloroform but quickly precipitate at room temperature. The ${ }^{1} \mathrm{H}$ NMR spectra of 6 and 7 show singlets and multiplets for the $-\mathrm{CH}_{2}-(4.81 \mathrm{ppm}$ for $6,4.74 \mathrm{ppm}$

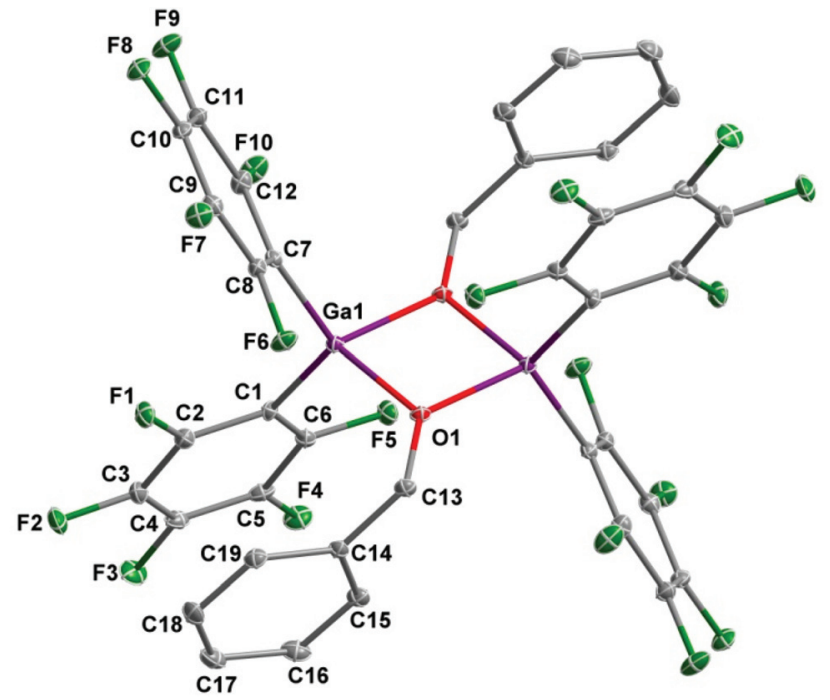

Fig. 5 Solid state structure of 7 (thermal ellipsoids are shown at 30\% probability levels); $\mathrm{H}$ atoms are omitted for clarity. Selected bond lengths and angles in $\AA$ and ${ }^{\circ}: \mathrm{Ga}(1)-\mathrm{O}(1)$ 1.913(2), Ga(1)-O(1)\#1 1.915(2), $\mathrm{Ga}(1)-C(1)$ 1.963(3), Ga(1)-C(7) 1.972(3), Ga(1)-Ga(1)\#1 2.9603(7), O(1)$C(13)$ 1.451(4), O(1)-Ga(1)\#1 1.915(2), C(13)-C(14) 1.494(4), O(1)-Ga(1)$\mathrm{O}(1) \# 1$ 78.7(2), O(1)-Ga(1)-C(1) 113.4(2), O(1)\#1-Ga(1)-C(1) 112.9(1), $\mathrm{O}(1)-\mathrm{Ga}(1)-\mathrm{C}(7)$ 109.9(1), O(1)\#1-Ga(1)-C(7) 114.1(1), C(1)-Ga(1)-C(7) 120.5(2), O(1)-Ga(1)-Ga(1)\#1 39.4(1), O(1)\#1-Ga(1)-Ga(1)\#1 39.3(1), $\mathrm{C}(1)-\mathrm{Ga}(1)-\mathrm{Ga}(1) \# 1$ 120.5(1), C(7)-Ga(1)-Ga(1)\#1 118.9(1), C(13)-O(1)$\mathrm{Ga}(1) \quad 130.4(2), \quad \mathrm{C}(13)-\mathrm{O}(1)-\mathrm{Ga}(1) \# 1 \quad$ 128.2(2), $\mathrm{Ga}(1)-\mathrm{O}(1)-\mathrm{Ga}(1) \# 1$ 101.3(1), O(1)-C(13)-C(14) 110.7(2).

for 7) and phenyl protons (6.99-6.66 ppm for 6 and 7), while ${ }^{13} \mathrm{C}\left\{{ }^{1} \mathrm{H}\right\}$ NMR spectra could not be obtained due to their limited solubility.

The molecular structure of 7 was confirmed by singlecrystal X-ray diffraction. Colourless crystals of 7 were obtained upon slow cooling of a warm benzene solution of 7 to room temperature. 7 crystallises in the triclinic space group $P \overline{1}$. The four-membered $\mathrm{Ga}_{2} \mathrm{O}_{2}$ ring possesses a planar structure with the distorted tetrahedral geometries for the $\mathrm{Ga}$ atoms. The $\mathrm{CH}_{2} \mathrm{Ph}$ groups adopt a trans-orientation with an O1-C13-C14 angle of $110.7(2)^{\circ}$. The endo- and exocyclic bond angles within the $\mathrm{Ga}_{2} \mathrm{O}_{2}$ ring are $78.7(1)^{\circ}\left(\mathrm{O} 1-\mathrm{Ga} 1-\mathrm{O} 1^{*}\right)$ and $101.3(1)^{\circ}(\mathrm{Ga} 1-$ O1-Ga1*), respectively. The Ga1-O1 (1.913(2) Å) and Ga1-O1* (1.915(2) $\AA$ ) bond distances are almost identical (Fig. 5).

\section{Conclusions}

Benzaldehyde readily reacts with the Lewis acid-base adducts $\left[\mathrm{LGa}-\mathrm{M}\left(\mathrm{C}_{6} \mathrm{~F}_{5}\right)_{3}\right](\mathrm{M}=\mathrm{B} \mathbf{1}, \mathrm{Al} 2)$, which were quantitatively formed in the reaction of $\mathrm{LGa}$ and $\mathrm{M}\left(\mathrm{C}_{6} \mathrm{~F}_{5}\right)_{3}$, with the formation of the insertion product 4 as well as the zwitterionic compound 5. $\mathbf{5}$ is formed by the attack of the strongly Lewisacidic aluminum atom on the $\gamma$-C atom of the $\beta$-diketiminate ligand. At elevated temperatures, 5 further reacts with subsequent activation of the $\gamma$-CH group and formation of 6 as well as so far unidentified compounds. A similar decompo- 
sition product 7 was obtained from the analogous reaction of $\left[\mathrm{LGa}-\mathrm{Ga}\left(\mathrm{C}_{6} \mathrm{~F}_{5}\right)_{3}\right] 3$ and benzaldehyde, while the insertion analogue of 5 could not be isolated. The activation of other organic derivatives upon reaction with Lewis acid-base adducts derived from monovalent group 13 diyls is currently being investigated in our laboratory in order to obtain a deeper understanding of the mechanism of main-group element based homogeneous catalysis reactions.

\section{Experimental}

All manipulations were performed under an atmosphere of purified argon using standard Schlenk and glove-box techniques. Toluene and hexane were dried using a mBraun Solvent Purification System. Benzene was carefully dried over Na. Deuterated solvents were dried over activated molecular sieves $(4 \AA)$ and degassed prior to use. The anhydrous nature of the solvents was verified by Karl Fischer titration. LGa $\left\{\mathrm{L}=\mathrm{HC}\left[\mathrm{C}(\mathrm{Me}) \mathrm{N}\left(2,6{ }^{\mathrm{i}} \mathrm{Pr}_{2} \mathrm{C}_{6} \mathrm{H}_{3}\right)\right]_{2}\right\},{ }^{7} \mathrm{~B}\left(\mathrm{C}_{6} \mathrm{~F}_{5}\right)_{3},{ }^{30} \mathrm{Ga}\left(\mathrm{C}_{6} \mathrm{~F}_{5}\right)_{3} \cdot \mathrm{OEt}_{2},{ }^{31}$ $\mathrm{Al}\left(\mathrm{C}_{6} \mathrm{~F}_{5}\right)_{3}(\text { toluene })_{0.5},{ }^{32}$ and $\left[\mathrm{LGa}-\mathrm{B}\left(\mathrm{C}_{6} \mathrm{~F}_{5}\right)_{3}\right]^{9}$ were prepared according to literature methods and other chemicals were obtained from commercial sources and purified prior to use. The ${ }^{1} \mathrm{H}(300.1 \mathrm{MHz}),{ }^{13} \mathrm{C}\left\{{ }^{1} \mathrm{H}\right\}(75.5 \mathrm{MHz})$ and ${ }^{19} \mathrm{~F}(282.4 \mathrm{MHz})$ NMR ( $\delta$ in ppm) spectra were recorded using a Bruker Avance DPX-300 spectrometer and the spectra were referenced to internal $\mathrm{C}_{6} \mathrm{D}_{5} \mathrm{H}\left({ }^{1} \mathrm{H}: \delta=7.154 ;{ }^{13} \mathrm{C}: \delta=128.39\right)$. The microanalyses were performed at the elemental analysis laboratory of the University of Duisburg-Essen. IR spectra were recorded with an ALPHA-T FT-IR spectrometer equipped with a single reflection ATR sampling module. The IR spectrometer was placed in a glovebox to guarantee measurements under inert gas conditions. The melting points were measured using a Thermo Scientific 9300 apparatus.

\section{Synthesis of 2}

A mixture of LGa (200 $\mathrm{mg}, 0.410 \quad \mathrm{mmol})$ and $\mathrm{Al}\left(\mathrm{C}_{6} \mathrm{~F}_{5}\right)_{3}\left(\mathrm{C}_{6} \mathrm{H}_{5} \mathrm{CH}_{3}\right)_{0.5}(236 \mathrm{mg}, 0.410 \mathrm{mmol})$ in $5 \mathrm{~mL}$ of benzene was stirred at room temperature for $4 \mathrm{~h}$. The solution was concentrated to $2 \mathrm{~mL}$ and kept at room temperature for 1 day to afford colorless crystals of 2. Yield: $315 \mathrm{mg}$ (0.310 mmol, 76\%). M.pt: $219{ }^{\circ} \mathrm{C}$. Anal. calcd for $\mathrm{C}_{47} \mathrm{H}_{41} \mathrm{~N}_{2} \mathrm{AlF}_{15} \mathrm{Ga}$ : C, 55.59; H, 4.07; N, 2.76. Found: C, 56.00; $\mathrm{H}, 4.09 ; \mathrm{N}, 2.89 \%$. IR (neat): $\nu$ 2965, 2931, 2871, 1638, 1540, 1506, 1439, 1377, 1361, 1316, 1261, 1178, 1106, 1065, 1054, 1024, 952, 869, 800, 760, 743, 719, 646, 606, 581, 528, 498, 448, $388 \mathrm{~cm}^{-1}$. ${ }^{1} \mathrm{H}$ NMR $\left(\mathrm{C}_{6} \mathrm{D}_{6}, 300.1 \mathrm{MHz}\right): \delta 7.01\left(\mathrm{t},{ }^{3} J_{\mathrm{HH}}=7.8 \mathrm{~Hz}\right.$, $\left.2 \mathrm{H}, \mathrm{C}_{6} H_{3}\left({ }^{\mathrm{i}} \mathrm{Pr}\right)_{2}\right), 6.79\left(\mathrm{~d},{ }^{3} J_{\mathrm{HH}}=7.8 \mathrm{~Hz}, 4 \mathrm{H}, \mathrm{C}_{6} \mathrm{H}_{3}\left({ }^{\mathrm{i}} \mathrm{Pr}\right)_{2}\right), 5.07(\mathrm{~s}$, $1 \mathrm{H}, \gamma-\mathrm{CH}-$ ), 2.75 (sept, $\left.{ }^{3} J_{\mathrm{HH}}=6.9 \mathrm{~Hz}, 4 \mathrm{H},-\mathrm{CH}\left(\mathrm{CH}_{3}\right)_{2}\right), 1.46(\mathrm{~s}$, $\left.6 \mathrm{H}, \mathrm{ArNCCH}_{3}\right), 1.01\left(\mathrm{~d},{ }^{3} J_{\mathrm{HH}}=6.9 \mathrm{~Hz}, 12 \mathrm{H},-\mathrm{CH}\left(\mathrm{CH}_{3}\right)_{2}\right), 0.90$ $\left(\mathrm{d},{ }^{3} \mathrm{~J}_{\mathrm{HH}}=6.9 \mathrm{~Hz}, 12 \mathrm{H},-\mathrm{CH}\left(\mathrm{CH}_{3}\right)_{2}\right) .{ }^{13} \mathrm{C} \mathrm{NMR}\left(\mathrm{C}_{6} \mathrm{D}_{6}\right.$, $75.5 \mathrm{MHz}): \delta 170.38\left(\mathrm{ArNCCH}_{3}\right), 151.78\left(C_{6} \mathrm{~F}_{5}\right), 148.71\left(C_{6} \mathrm{~F}_{5}\right)$, $142.97\left(\mathrm{NC}\right.$ of $\left.C_{6} \mathrm{H}_{3}\right), 139.82\left(o-\mathrm{C}\right.$ of $\left.C_{6} \mathrm{H}_{3}\right), 138.87\left(C_{6} \mathrm{~F}_{5}\right)$, $135.57\left(C_{6} \mathrm{~F}_{5}\right), 129.03\left(m-\mathrm{C}\right.$ of $\left.C_{6} \mathrm{H}_{3}\right), 124.92\left(p-\mathrm{C}\right.$ of $\left.C_{6} \mathrm{H}_{3}\right)$, 102.37 ( $\gamma$-CH-), $29.71\left(-\mathrm{CH}\left(\mathrm{CH}_{3}\right)_{2}\right), 24.74\left(\mathrm{ArNCCH}_{3}\right), 24.11$
$\left(-\mathrm{CH}\left(\mathrm{CH}_{3}\right)_{2}\right), 23.91\left(-\mathrm{CH}\left(\mathrm{CH}_{3}\right)_{2}\right) .{ }^{19} \mathrm{~F} \mathrm{NMR}\left(\mathrm{C}_{6} \mathrm{D}_{6}, 282.4 \mathrm{MHz}\right)$ : $\delta-118.95(\mathrm{~m}),-154.39\left(\mathrm{t},{ }^{3} J_{\mathrm{FF}}=20 \mathrm{~Hz}\right),-161.43(\mathrm{~m})$.

\section{Synthesis of 3}

3 was synthesized by following the procedure of 2 using LGa (400 $\mathrm{mg}, \quad 0.821 \mathrm{mmol})$ and $\mathrm{Ga}\left(\mathrm{C}_{6} \mathrm{~F}_{5}\right)_{3} \cdot \mathrm{OEt}_{2}$ (529 $\mathrm{mg}$, $0.821 \mathrm{mmol})$. Yield: $770 \mathrm{mg}(0.727 \mathrm{mmol}, 89 \%)$. M.pt: $220{ }^{\circ} \mathrm{C}$. Anal. calcd for $\mathrm{C}_{47} \mathrm{H}_{41} \mathrm{~N}_{2} \mathrm{~F}_{15} \mathrm{Ga}_{2}$ : C, 53.34; H, 3.91; N, 2.65. Found: C, 53.80; H, 3.92; N, 2.64\%. IR (neat): $\nu$ 2965, 2931, 2871, 1638, 1541, 1505, 1457, 1440, 1362, 1316, 1260, 1178, 1062, 1053, 1025, 953, 870, 800, 788, 760, 717, 645, 606, 528, 488, 445, $385 \mathrm{~cm}^{-1} .{ }^{1} \mathrm{H}$ NMR $\left(\mathrm{C}_{6} \mathrm{D}_{6}, 300.1 \mathrm{MHz}\right): \delta 7.00(\mathrm{t}$, $\left.{ }^{3} J_{\mathrm{HH}}=7.8 \mathrm{~Hz}, 2 \mathrm{H}, \mathrm{C}_{6} \mathrm{H}_{3}\left({ }^{\mathrm{i}} \mathrm{Pr}\right)_{2}\right), 6.78\left(\mathrm{~d},{ }^{3} J_{\mathrm{HH}}=7.8 \mathrm{~Hz}, 4 \mathrm{H}\right.$, $\left.\mathrm{C}_{6} H_{3}\left({ }^{\mathrm{i}} \mathrm{Pr}\right)_{2}\right), 5.05$ (s, $\left.1 \mathrm{H}, \gamma-\mathrm{CH}-\right), 2.75$ (sept, ${ }^{3} J_{\mathrm{HH}}=6.9 \mathrm{~Hz}, 4 \mathrm{H}$, $\left.-\mathrm{CH}\left(\mathrm{CH}_{3}\right)_{2}\right), 1.46\left(\mathrm{~s}, 6 \mathrm{H}, \operatorname{ArNCCH}_{3}\right), 1.01\left(\mathrm{~d},{ }^{3} J_{\mathrm{HH}}=6.6 \mathrm{~Hz}\right.$, $\left.12 \mathrm{H},-\mathrm{CH}\left(\mathrm{CH}_{3}\right)_{2}\right), 0.90\left(\mathrm{~d},{ }^{3} J_{\mathrm{HH}}=6.9 \mathrm{~Hz}, 12 \mathrm{H}, J=6.6 \mathrm{~Hz},-\mathrm{CH}\right.$ $\left.\left(\mathrm{CH}_{3}\right)_{2}\right) \cdot{ }^{13} \mathrm{C} \mathrm{NMR}\left(\mathrm{C}_{6} \mathrm{D}_{6}, 75.5 \mathrm{MHz}\right): \delta 170.78\left(\mathrm{ArNCCH}_{3}\right)$, $150.87\left(C_{6} \mathrm{~F}_{5}\right), 147.74\left(C_{6} \mathrm{~F}_{5}\right), 142.97\left(\mathrm{NC}\right.$ of $\left.C_{6} \mathrm{H}_{3}\right), 139.63(o-\mathrm{C}$ of $\left.C_{6} \mathrm{H}_{3}\right), 139.03\left(C_{6} \mathrm{~F}_{5}\right), 135.55\left(C_{6} \mathrm{~F}_{5}\right), 129.08\left(m-\mathrm{C}\right.$ of $\left.C_{6} \mathrm{H}_{3}\right)$, $124.95\left(p-\mathrm{C}\right.$ of $\left.C_{6} \mathrm{H}_{3}\right), 102.34(\gamma-\mathrm{CH}-), 29.80\left(-\mathrm{CH}\left(\mathrm{CH}_{3}\right)_{2}\right), 24.76$ $\left(\mathrm{ArNCCH}_{3}\right), 24.01\left(-\mathrm{CH}\left(\mathrm{CH}_{3}\right)_{2}\right), 23.94\left(-\mathrm{CH}\left(\mathrm{CH}_{3}\right)_{2}\right) .{ }^{19} \mathrm{~F} \mathrm{NMR}$ $\left(\mathrm{C}_{6} \mathrm{D}_{6}, 282.4 \mathrm{MHz}\right): \delta-119.61(\mathrm{~m}),-155.85\left(\mathrm{t},{ }^{3} J_{\mathrm{FF}}=20 \mathrm{~Hz}\right)$, $-161.63(\mathrm{~m})$.

\section{Synthesis of 4}

[LGa-B $\left.\left(\mathrm{C}_{6} \mathrm{~F}_{5}\right)_{3}\right]$ (1) (410 mg, $\left.0.410 \mathrm{mmol}\right)$ was dissolved in $4 \mathrm{~mL}$ of toluene. Benzaldehyde (43.5 $\mathrm{mg}, 42 \mu \mathrm{L}, 0.410 \mathrm{mmol}$ ) was added to the above solution and the reaction mixture was stirred at room temperature for $2 \mathrm{~h}$. The solution was concentrated to $2 \mathrm{~mL}$, layered with $1 \mathrm{~mL}$ of hexane and stored at $-30{ }^{\circ} \mathrm{C}$ for 2 days to afford colorless microcrystals of 4 . Yield: $356 \mathrm{mg}$ (0.322 mmol, 78\%). M.pt: $200{ }^{\circ} \mathrm{C}$. Anal. calcd for $\mathrm{C}_{54} \mathrm{H}_{47} \mathrm{~N}_{2} \mathrm{BF}_{15} \mathrm{GaO}$ : C, 58.67; H, 4.29; N, 2.53. Found: C, 58.80; $\mathrm{H}, 4.30 ; \mathrm{N}, 2.56 \%$. IR (neat): $\nu$ 2968, 2930, 2871, 1651, 1520, 1481, 1455, 1439, 1385, 1312, 1258, 1174, 1145, 1093, 1073, 1054, 1017, 974, 961, 936, 916, 866, 842, 801, 776, 760, 740, $707,626,594,578,552,531,515,501,485,441 \mathrm{~cm}^{-1} .{ }^{1} \mathrm{H}$ NMR $\left(\mathrm{C}_{6} \mathrm{D}_{6}, 300.1 \mathrm{MHz}\right): \delta$ 7.13-6.39 $\left(\mathrm{m}, 11 \mathrm{H}, \mathrm{C}_{6} \mathrm{H}_{3}\left({ }^{\mathrm{i}} \mathrm{Pr}\right)_{2}, \mathrm{C}_{6} H_{5}\right)$, 5.89 (s, $1 \mathrm{H},-\mathrm{CH}-\mathrm{Ph}$ ), 5.00 (s, $1 \mathrm{H}, \gamma-\mathrm{CH}-$ ), 3.47 (two sept, $\left.{ }^{3} J_{\mathrm{HH}}=6.9 \mathrm{~Hz}, 2 \mathrm{H},-\mathrm{CH}\left(\mathrm{CH}_{3}\right)_{2}\right), 2.71\left(\mathrm{sept},{ }^{3} J_{\mathrm{HH}}=6.6 \mathrm{~Hz}, 1 \mathrm{H}\right.$, $\left.-\mathrm{CH}\left(\mathrm{CH}_{3}\right)_{2}\right), 2.47\left(\mathrm{sept},{ }^{3} \mathrm{~J}_{\mathrm{HH}}=6.6 \mathrm{~Hz}, 1 \mathrm{H},-\mathrm{CH}\left(\mathrm{CH}_{3}\right)_{2}\right), 1.63(\mathrm{~d}$, $\left.{ }^{3} J_{\mathrm{HH}}=6.9 \mathrm{~Hz}, 3 \mathrm{H},-\mathrm{CH}\left(\mathrm{CH}_{3}\right)_{2}\right), 1.49\left(\mathrm{~s}, 3 \mathrm{H}, \operatorname{ArNCCH}_{3}\right), 1.43$ $\left(\mathrm{d},{ }^{3} J_{\mathrm{HH}}=6.9 \mathrm{~Hz}, 3 \mathrm{H},-\mathrm{CH}\left(\mathrm{CH}_{3}\right)_{2}\right), 1.33\left(\mathrm{~s}, 3 \mathrm{H}, \operatorname{ArNCCH}_{3}\right)$, $1.16\left(\mathrm{~d},{ }^{3} \mathrm{~J}_{\mathrm{HH}}=6.9 \mathrm{~Hz}, 3 \mathrm{H},-\mathrm{CH}\left(\mathrm{CH}_{3}\right)_{2}\right), 1.03\left(\mathrm{~d},{ }^{3} J_{\mathrm{HH}}=6.6 \mathrm{~Hz}\right.$, $\left.3 \mathrm{H},-\mathrm{CH}\left(\mathrm{CH}_{3}\right)_{2}\right), 0.98\left(\mathrm{~d},{ }^{3} J_{\mathrm{HH}}=6.6 \mathrm{~Hz}, 3 \mathrm{H},-\mathrm{CH}\left(\mathrm{CH}_{3}\right)_{2}\right), 0.83$ (two overlapping d, $\left.{ }^{3} J_{\mathrm{HH}}=6.6 \mathrm{~Hz}, 6 \mathrm{H},-\mathrm{CH}\left(\mathrm{CH}_{3}\right)_{2}\right),-0.34$ (d, $\left.{ }^{3} J_{\mathrm{HH}}=6.9 \mathrm{~Hz}, 3 \mathrm{H},-\mathrm{CH}\left(\mathrm{CH}_{3}\right)_{2}\right) .{ }^{13} \mathrm{C} \mathrm{NMR}\left(\mathrm{C}_{6} \mathrm{D}_{6}, 75.5 \mathrm{MHz}\right)$ : $\delta 171.32\left(\mathrm{ArNCCH}_{3}\right), 171.27\left(\mathrm{ArNCCH}_{3}\right), 170.92\left(\mathrm{ArNCCH}_{3}\right)$, $148.58\left(C_{6} \mathrm{~F}_{5}\right), 145.73\left(C_{6} \mathrm{H}_{3}\right), 145.34\left(C_{6} \mathrm{~F}_{5}\right), 144.82\left(C_{6} \mathrm{H}_{3}\right)$, $144.23\left(C_{6} \mathrm{H}_{3}\right), 142.89\left(C_{6} \mathrm{H}_{3}\right), 142.71\left(C_{6} \mathrm{H}_{3}\right), 142.65\left(C_{6} \mathrm{H}_{3}\right)$, $142.12\left(C_{6} \mathrm{H}_{3}\right), 140.94\left(C_{6} \mathrm{~F}_{5}\right), 139.97\left(C_{6} \mathrm{~F}_{5}\right), 139.20\left(C_{6} \mathrm{~F}_{5}\right)$, $135.87\left(C_{6} \mathrm{~F}_{5}\right), 128.26\left(C_{6} \mathrm{H}_{3}\right), 126.65\left(C_{6} \mathrm{H}_{3}\right), 126.03\left(C_{6} \mathrm{H}_{3}\right)$, $125.80\left(C_{6} \mathrm{H}_{3}\right), 125.34\left(C_{6} \mathrm{H}_{3}\right), 125.21\left(C_{6} \mathrm{H}_{3}\right), 124.78\left(C_{6} \mathrm{H}_{3}\right)$, $123.47\left(C_{6} \mathrm{H}_{3}\right), 100.03$ ( $\left.\gamma-\mathrm{CH}-\right), 99.93(\gamma-C \mathrm{H}-), 82.34(-\mathrm{CH}-\mathrm{Ph})$, $29.96\left(-\mathrm{CH}\left(\mathrm{CH}_{3}\right)_{2}\right), 29.15\left(-\mathrm{CH}\left(\mathrm{CH}_{3}\right)_{2}\right), 28.46\left(-\mathrm{CH}\left(\mathrm{CH}_{3}\right)_{2}\right)$, $27.73\left(-\mathrm{CH}\left(\mathrm{CH}_{3}\right)_{2}\right), 27.68\left(\mathrm{ArNCCH}_{3}\right), 25.58\left(\mathrm{ArNCCH}_{3}\right), 25.31$ 
$\left(-\mathrm{CH}\left(\mathrm{CH}_{3}\right)_{2}\right), 25.16 \quad\left(-\mathrm{CH}\left(\mathrm{CH}_{3}\right)_{2}\right), 25.03 \quad\left(-\mathrm{CH}\left(\mathrm{CH}_{3}\right)_{2}\right), 24.68$ $\left(-\mathrm{CH}\left(\mathrm{CH}_{3}\right)_{2}\right), 24.50 \quad\left(-\mathrm{CH}\left(\mathrm{CH}_{3}\right)_{2}\right), 24.30 \quad\left(-\mathrm{CH}\left(\mathrm{CH}_{3}\right)_{2}\right), 24.16$ $\left(-\mathrm{CH}\left(\mathrm{CH}_{3}\right)_{2}\right), 22.43\left(-\mathrm{CH}\left(\mathrm{CH}_{3}\right)_{2}\right) .{ }^{19} \mathrm{~F} \mathrm{NMR}\left(\mathrm{C}_{6} \mathrm{D}_{6}, 282.4 \mathrm{MHz}\right)$ : $\delta-110.58(\mathrm{~m}),-115.42(\mathrm{~m}),-131.06(\mathrm{~m}),-152.11\left(\mathrm{t},{ }^{3} J_{\mathrm{FF}}=\right.$ $20 \mathrm{~Hz}),-153.73\left(\mathrm{t},{ }^{3} J_{\mathrm{FF}}=20 \mathrm{~Hz}\right),-160.97(\mathrm{~m}),-161.80(\mathrm{~m})$, $-162.57(\mathrm{~m})$.

\section{Synthesis of 5}

[LGa-Al $\left.\left(\mathrm{C}_{6} \mathrm{~F}_{5}\right)_{3}\right]$ (2) (100 mg, $\left.0.098 \mathrm{mmol}\right)$ was dissolved in $0.5 \mathrm{~mL}$ of benzene and benzaldehyde $(10.4 \mathrm{mg}, 10 \mu \mathrm{L}$, $0.098 \mathrm{mmol}$ ) was added. The solution was stirred at room temperature for 30 minutes and stored at $9{ }^{\circ} \mathrm{C}$ for 1 day to afford colorless crystals of 5. Yield: $77 \mathrm{mg}$ (0.069 mmol, 70\%). Anal. calcd for $\mathrm{C}_{54} \mathrm{H}_{47} \mathrm{~N}_{2} \mathrm{AlF}_{15} \mathrm{GaO}$ : C, 57.82; H, 4.22; N, 2.50 . Found: C, 58.80; H, 4.30; N, 2.56\%. IR (neat): $\nu$ 2968, 2932, 2872, 1638, 1595, 1582, 1531, 1509, 1443, 1387, 1366, 1317, 1272, 1225, 1178, 1165, 1068, 1025, 958, 865, 843, 798, 753, 721, 700, 652, 615, 582, 517, 497, 445, $404 \mathrm{~cm}^{-1} \cdot{ }^{1} \mathrm{H}$ NMR $\left(\mathrm{C}_{6} \mathrm{D}_{6}, 300.1 \mathrm{MHz}\right): \delta$ 7.79-6.69 $\left(\mathrm{m}, 11 \mathrm{H}, \mathrm{C}_{6} H_{3}\left({ }^{\mathrm{i}} \mathrm{Pr}\right)_{2}, \mathrm{C}_{6} H_{5}\right)$, $6.42(\mathrm{~s}, 1 \mathrm{H},-\mathrm{CH}-\mathrm{Ph}), 4.71(\mathrm{~s}, 1 \mathrm{H}, \gamma-\mathrm{CH}-), 3.26\left(\mathrm{sept},{ }^{3} J_{\mathrm{HH}}=\right.$ $\left.6.6 \mathrm{~Hz}, 1 \mathrm{H},-\mathrm{CH}\left(\mathrm{CH}_{3}\right)_{2}\right), 2.88\left(\mathrm{sept},{ }^{3} J_{\mathrm{HH}}=6.6 \mathrm{~Hz}, 1 \mathrm{H}\right.$, $\left.-\mathrm{CH}\left(\mathrm{CH}_{3}\right)_{2}\right), 2.57\left(\mathrm{sept},{ }^{3} J_{\mathrm{HH}}=6.9 \mathrm{~Hz}, 1 \mathrm{H},-\mathrm{CH}\left(\mathrm{CH}_{3}\right)_{2}\right), 2.41$ (sept, $\left.{ }^{3} J_{\mathrm{HH}}=6.9 \mathrm{~Hz}, 1 \mathrm{H},-\mathrm{CH}\left(\mathrm{CH}_{3}\right)_{2}\right), 1.55\left(\mathrm{~s}, 3 \mathrm{H}, \mathrm{ArNCCH}_{3}\right)$, $1.53\left(\mathrm{~s}, 3 \mathrm{H}, \operatorname{ArNCCH}_{3}\right), 1.24\left(\mathrm{~d},{ }^{3} \mathrm{~J}_{\mathrm{HH}}=6.6 \mathrm{~Hz}, 3 \mathrm{H},-\mathrm{CH}\right.$ $\left(\mathrm{CH}_{3}\right)_{2}$ ), 1.06 (two overlapping d, ${ }^{3} \mathrm{~J}_{\mathrm{HH}}=6.6 \mathrm{~Hz}, 6 \mathrm{H},-\mathrm{CH}$ $\left.\left(\mathrm{CH}_{3}\right)_{2}\right), 0.98\left(\mathrm{~d},{ }^{3} J_{\mathrm{HH}}=6.9 \mathrm{~Hz}, 3 \mathrm{H},-\mathrm{CH}\left(\mathrm{CH}_{3}\right)_{2}\right), 0.61\left(\mathrm{~d},{ }^{3} J_{\mathrm{HH}}=\right.$ $6.6 \mathrm{~Hz}, 3 \mathrm{H},-\mathrm{CH}\left(\mathrm{CH}_{3}\right)_{2}$ ), 0.44 (three overlapping d, $9 \mathrm{H},-\mathrm{CH}$ $\left.\left(\mathrm{CH}_{3}\right)_{2}\right) .{ }^{13} \mathrm{C} \mathrm{NMR}\left(\mathrm{C}_{6} \mathrm{D}_{6}, 75.5 \mathrm{MHz}\right): \delta 188.56\left(\mathrm{ArNCCH}_{3}\right)$, $186.86\left(\mathrm{ArNCCH}_{3}\right), 152.11\left(C_{6} \mathrm{~F}_{5}\right), 150.39\left(C_{6} \mathrm{~F}_{5}\right), 149.00\left(C_{6} \mathrm{~F}_{5}\right)$, $148.42\left(C_{6} \mathrm{H}_{3}\right), 147.15\left(C_{6} \mathrm{~F}_{5}\right), 144.41\left(C_{6} \mathrm{H}_{3}\right), 143.98\left(C_{6} \mathrm{~F}_{5}\right)$, $143.37\left(C_{6} \mathrm{H}_{3}\right), 141.36\left(C_{6} \mathrm{H}_{3}\right), 141.28\left(C_{6} \mathrm{H}_{3}\right), 140.67\left(C_{6} \mathrm{~F}_{5}\right)$, $139.86\left(C_{6} \mathrm{H}_{3}\right), 139.25\left(C_{6} \mathrm{H}_{3}\right), 136.16\left(C_{6} \mathrm{~F}_{5}\right), 129.19\left(C_{6} \mathrm{H}_{3}\right)$, $129.09\left(C_{6} \mathrm{H}_{3}\right), 128.91\left(C_{6} \mathrm{H}_{3}\right), 126.80\left(C_{6} \mathrm{H}_{3}\right), 126.36\left(C_{6} \mathrm{H}_{3}\right)$, $125.43\left(C_{6} \mathrm{H}_{3}\right), 125.16\left(C_{6} \mathrm{H}_{3}\right), 124.19\left(C_{6} \mathrm{H}_{3}\right), 123.81\left(C_{6} \mathrm{H}_{3}\right)$, 73.25 (-CH-Ph), $71.10(\gamma-C \mathrm{H}-), 30.05\left(-\mathrm{CH}\left(\mathrm{CH}_{3}\right)_{2}\right), 29.47(-\mathrm{CH}$ $\left.\left(\mathrm{CH}_{3}\right)_{2}\right), \quad 29.28 \quad\left(-\mathrm{CH}\left(\mathrm{CH}_{3}\right)_{2}\right), \quad 28.21 \quad\left(-\mathrm{CH}\left(\mathrm{CH}_{3}\right)_{2}\right), \quad 26.76$ $\left(\mathrm{ArNCCH}_{3}\right), 26.34\left(\mathrm{ArNCCH}_{3}\right), 25.50\left(-\mathrm{CH}\left(\mathrm{CH}_{3}\right)_{2}\right), 25.47(-\mathrm{CH}$ $\left.\left(\mathrm{CH}_{3}\right)_{2}\right), 25.24\left(-\mathrm{CH}\left(\mathrm{CH}_{3}\right)_{2}\right), 24.88\left(-\mathrm{CH}\left(\mathrm{CH}_{3}\right)_{2}\right), 24.84(-\mathrm{CH}$ $\left.\left(\mathrm{CH}_{3}\right)_{2}\right), 24.32\left(-\mathrm{CH}\left(\mathrm{CH}_{3}\right)_{2}\right), 23.62\left(-\mathrm{CH}\left(\mathrm{CH}_{3}\right)_{2}\right), 21.93(-\mathrm{CH}$ $\left.\left(\mathrm{CH}_{3}\right)_{2}\right) .{ }^{19} \mathrm{~F}$ NMR $\left(\mathrm{C}_{6} \mathrm{D}_{6}, 282.4 \mathrm{MHz}\right): \delta-115.76(\mathrm{~m}),-119.01$ $(\mathrm{m}),-120.62(\mathrm{~m}),-150.84\left(\mathrm{t},{ }^{3} J_{\mathrm{FF}}=20 \mathrm{~Hz}\right),-152.44(\mathrm{~m})$, $-160.37(\mathrm{~m}),-160.85(\mathrm{~m})$.

\section{Synthesis of 6}

A solution of $5(100 \mathrm{mg}, 0.089 \mathrm{mmol})$ in $0.5 \mathrm{~mL}$ of $\mathrm{C}_{6} \mathrm{D}_{6}$ was heated at $80{ }^{\circ} \mathrm{C}$ for $4 \mathrm{~h}$ in a J-Young NMR tube. The reaction mixture was kept at room temperature for 2 days to afford 6 as a colorless microcrystalline solid. Yield: $37 \mathrm{mg}(0.039 \mathrm{mmol}$, 88\%). M.pt: $>300{ }^{\circ} \mathrm{C}$. Anal. calcd for $\mathrm{C}_{38} \mathrm{H}_{14} \mathrm{Al}_{2} \mathrm{~F}_{20} \mathrm{O}_{2}$ : C, 48.74; $\mathrm{H}, 1.51$. Found: C, 48.50; H, 1.69\%. IR (neat): $\nu$ 1643, 1512, 1449, 1381, 1364, 1279, 1216, 1069, 956, 919, 828, 755, 701, 664, 611, 575, 543, 511, 464, $425 \mathrm{~cm}^{-1} \cdot{ }^{1} \mathrm{H}$ NMR $\left(\mathrm{C}_{6} \mathrm{D}_{6}\right.$, $300.1 \mathrm{MHz}): \delta 6.97\left(\mathrm{~m}, 2 \mathrm{H}, \mathrm{C}_{6} H_{5}\right), 6.71\left(\mathrm{~m}, 3 \mathrm{H}, \mathrm{C}_{6} H_{5}\right), 4.81$ $\left(\mathrm{s}, 2 \mathrm{H},-\mathrm{OCH}_{2}-\right) .{ }^{19} \mathrm{~F}$ NMR $\left(\mathrm{C}_{6} \mathrm{D}_{6}, 282.4 \mathrm{MHz}\right): \delta-122.03(\mathrm{~m})$, $-149.33\left(\mathrm{t},{ }^{3} J_{\mathrm{FF}}=20 \mathrm{~Hz}\right),-160.01(\mathrm{~m})$.

\section{Synthesis of 7}

A solution of $\left[\mathrm{LGa}-\mathrm{Ga}\left(\mathrm{C}_{6} \mathrm{~F}_{5}\right)_{3}\right]$ (3) (208 mg, $\left.0.196 \mathrm{mmol}\right)$ and benzaldehyde $(20.8 \mathrm{mg}, 20 \mu \mathrm{L}, 0.196 \mathrm{mmol})$ in $1 \mathrm{~mL}$ of toluene was heated at $120{ }^{\circ} \mathrm{C}$ for 2 days. The reaction mixture was brought to room temperature and stored at $7{ }^{\circ} \mathrm{C}$ for 1 day to give colorless crystals of 7 . The crystals were washed twice with benzene $(2 \times 1 \mathrm{~mL})$. Yield: $18 \mathrm{mg}(0.0176 \mathrm{mmol}, 18 \%)$. M.pt: $247{ }^{\circ} \mathrm{C}$. Anal. calcd for $\mathrm{C}_{38} \mathrm{H}_{14} \mathrm{Ga}_{2} \mathrm{~F}_{20} \mathrm{O}_{2}$ : C, 44.66; H, 1.38 . Found: C, 44.52; H, 1.44\%. IR (neat): $\nu$ 1640, 1511, 1464, 1451, 1372, 1280, 1214, 1067, 1017, 959, 919, 825, 810, 753, 720, 700, 632, 608, 524, 495, $408 \mathrm{~cm}^{-1} .{ }^{1} \mathrm{H} \mathrm{NMR}\left(\mathrm{C}_{6} \mathrm{D}_{6}, 300.1 \mathrm{MHz}\right)$ : $\delta 6.98\left(\mathrm{~m}, 2 \mathrm{H}, \mathrm{C}_{6} H_{5}\right), 6.73\left(\mathrm{~m}, 3 \mathrm{H}, \mathrm{C}_{6} H_{5}\right), 4.74(\mathrm{~s}, 2 \mathrm{H}$, $\left.-\mathrm{OCH}_{2}-\right) .{ }^{19} \mathrm{~F}$ NMR $\left(\mathrm{C}_{6} \mathrm{D}_{6}, 282.4 \mathrm{MHz}\right): \delta-123.68(\mathrm{~m}),-149.50$ $\left(\mathrm{t},{ }^{3} J_{\mathrm{FF}}=20 \mathrm{~Hz}\right),-159.81(\mathrm{~m})$.

\section{Single crystal X-ray diffraction}

Crystallographic data of 2-4 and 7, $\$$ which were collected on a Bruker D8 Kappa APEX2 diffractometer $\left(\mathrm{MoK}_{\alpha}\right.$ radiation, $\lambda=$ $0.71073 \AA$ ) at $100(1) \mathrm{K}$, are summarized in Table S1. $\dagger$ The solid-state structures of 2-4 and 7 are shown in Fig. 1-4. The structures were solved by direct methods (SHELXS-97) ${ }^{33}$ and refined anisotropically by full-matrix least-squares on $F^{2}$ (SHELXL-2014). ${ }^{34}$ Absorption corrections were performed semi-empirically from equivalent reflections on the basis of multi-scans (Bruker AXS APEX2, TWINABS for 7). Hydrogen atoms were refined using a riding model or rigid methyl groups. The crystal of 7 was a non-merohedral twin and the structure model was refined against HKLF5 data. Details on the best model available for $\mathbf{5}$ are given in the ESI. $\dagger$

\section{Acknowledgements}

S. Schulz likes to thank the University of Duisburg-Essen for financial support.

\section{Notes and references}

1 (a) G. C. Welch, R. R. San Juan, J. D. Masuda and D. W. Stephan, Science, 2006, 314, 1124. For recent review articles see: (b) A. J. P. Cardenas, Y. Hasegawa, G. Kehr, T. H. Warren and G. Erker, Coord. Chem. Rev., 2016, 306, 468; (c) D. W. Stephan and G. Erker, Angew. Chem., 2015, 127, 6498, (Angew. Chem., Int. Ed., 2015, 54, 6400); (d) D. W. Stephan and G. Erker, Angew. Chem., 2010, 122, 50, (Angew. Chem., Int. Ed., 2010, 49, 46).

2 M. A. Dureen and D. W. Stephan, J. Am. Chem. Soc., 2009, 131, 8396.

3 (a) V. Sumerin, K. Chernichenko, F. Schulz, M. Leskelä, B. Rieger and T. Repo, Top. Curr. Chem., 2013, 332, 111;

(b) V. Sumerin, F. Schulz, M. Nieger, M. Leskelä, T. Repo

$\$$ The crystallographic data of $2,3,4$, and 7 (excluding structure factors) have been deposited with the Cambridge Crystallographic Data Centre as supplementary publication no. CCDC 1477155(2), 1477157(3), 1477158(4) and 1477156(7). 
and B. Rieger, Angew. Chem., 2008, 120, 6090, (Angew. Chem., Int. Ed., 2008, 47, 6001); (c) V. Sumerin, F. Schulz, M. Atsumi, C. Wang, M. Nieger, M. Leskelä, T. Repo, P. Pyykkö and B. Rieger, J. Am. Chem. Soc., 2008, 130, 14117; (d) M. Alcarazo, C. Gomez, S. Holle and R. Goddard, Angew. Chem., 2010, 122, 5924, (Angew. Chem., Int. Ed., 2010, 49, 5788).

4 (a) D. Holschumacher, T. Bannenberg, C. G. Hrib, P. G. Jones and M. Tamm, Angew. Chem., 2008, 120, 7538, (Angew. Chem., Int. Ed., 2008, 47, 7428); (b) E. L. Kolychev, E. Theuergarten and M. Tamm, Top. Curr. Chem., 2013, 334, 121; (c) Y. Hoshimoto, T. Kinoshita, M. Ohashi and S. Ogoshi, Angew. Chem., 2015, 127, 11832, (Angew. Chem., Int. Ed., 2015, 54, 11666).

5 (a) O. Ekkert, R. Fröhlich, G. Kehr and G. Erker, J. Am. Chem. Soc., 2011, 133, 4610; (b) T. Wiegand, H. Eckert, O. Ekkert, R. Fröhlich, G. Kehr, G. Erker and S. Grimme, J. Am. Chem. Soc., 2012, 134, 4236; (c) P. Spies, G. Erker, G. Kehr, K. Bergander, R. Fröhlich, S. Grimme and D. W. Stephan, Chem. Commun., 2007, 5072.

6 (a) G. Menard and D. W. Stephan, J. Am. Chem. Soc., 2010, 132, 1796; (b) Y. T. Zhang, G. M. Miyake and E. Y. X. Chen, Angew. Chem., 2010, 122, 10356, (Angew. Chem., Int. Ed., 2010, 49, 10158); (c) C. Appelt, H. Westenberg, F. Bertini, A. W. Ehlers, J. C. Slootweg, K. Lammertsma and W. Uhl, Angew. Chem., 2011, 123, 4011, (Angew. Chem., Int. Ed., 2011, 50, 3925); (d) G. Menard and D. W. Stephan, Angew. Chem., 2011, 123, 8546, (Angew. Chem., Int. Ed., 2011, 50, 8396); (e) S. Roters, C. Appelt, H. Westenberg, A. Hepp, J. C. Slootweg, K. Lammertsma and W. Uhl, Dalton Trans., 2012, 41, 9033; (f) C. Appelt, J. C. Slootweg, K. Lammertsma and W. Uhl, Angew. Chem., 2012, 124, 6013, (Angew. Chem., Int. Ed., 2012, 51, 5911); (g) G. Menard and D. W. Stephan, Angew. Chem., 2012, 124, 4485, (Angew. Chem., Int. Ed., 2012, 51, 4409); (h) C. Appelt, J. C. Slootweg, K. Lammertsma and W. Uhl, Angew. Chem., 2013, 125, 4350, (Angew. Chem., Int. Ed., 2013, 52, 4256); (i) G. Menard, J. A. Hatnean, H. J. Cowley, A. J. Lough, J. M. Rawson and D. W. Stephan, J. Am. Chem. Soc., 2013, 135, 6446; (j) F. Bertini, F. Hoffmann, C. Appelt, W. Uhl, A. W. Ehlers, J. C. Slootweg and K. Lammertsma, Organometallics, 2013, 32, 6764; (k) W. Uhl, C. Appelt, A. Wollschläger, A. Hepp and E.-U. Würthwein, Inorg. Chem., 2014, 53, 8991; (l) J. H. He, Y. T. Zhang, L. Falivene, L. Caporaso, L. Cavallo and E. Y. X. Chen, Macromolecules, 2014, 47, 7765; (m) J. H. He, Y. T. Zhang and E. Y. X. Chen, Synlett, 2014, 1534; (n) W. Uhl, C. Appelt and M. Lange, $Z$. Anorg. Allg. Chem., 2015, 641, 311; (o) J. Chen and E. X.-Y. Chen, Molecules, 2015, 20, 9575.

7 N. J. Hardman, B. E. Eichler and P. P. Power, J. Chem. Soc., Chem. Commun., 2000, 1991.

8 (a) N. J. Hardman and P. P. Power, ACS Symp. Ser., 2002, 822, 2; (b) C.-H. Chen, M.-L. Tsai and M.-D. Su, Organometallics, 2006, 25, 2766; (c) M. S. Hill, P. B. Hitchcock and R. Pontavornpinyo, Dalton Trans., 2005, 273.
9 N. J. Hardman, P. P. Power, J. D. Gorden, C. L. B. Macdonald and A. H. Cowley, J. Chem. Soc., Chem. Commun., 2001, 1866.

10 C. Gemel, T. Steinke, M. Cokoja, A. Kempter and R. A. Fischer, Eur. J. Inorg. Chem., 2004, 4161.

11 For a review article see: S. Schulz, Adv. Organomet. Chem., 2003, 49, 225.

12 (a) A. Kuczkowski, S. Schulz, M. Nieger and P. R. Schreiner, Organometallics, 2002, 21, 1408; (b) S. Schulz and M. Nieger, J. Chem. Soc., Dalton Trans., 2000, 5, 639; (c) S. Schulz, A. Kuczkowski and M. Nieger, J. Organomet. Chem., 2000, 604, 202; (d) A. Kuczkowski, F. Thomas, S. Schulz and M. Nieger, Organometallics, 2000, 19, 5758; (e) A. Kuczkowski, S. Schulz and M. Nieger, Eur. J. Inorg. Chem., 2001, 2605.

13 (a) A. Kuczkowski, S. Schulz and M. Nieger, Angew. Chem., 2001, 113, 4351, (Angew. Chem., Int. Ed., 2001, 40, 4222); (b) A. Kuczkowski, S. Schulz, M. Nieger and P. Saarenketo, Organometallics, 2001, 20, 2000; (c) A. Kuczkowski, S. Fahrenholz, S. Schulz and M. Nieger, Organometallics, 2004, 23, 3615; (d) D. Schuchmann, A. Kuczkowski, S. Fahrenholz, S. Schulz and U. Flörke, Eur. J. Inorg. Chem., 2007, 931.

14 S. Schulz, A. Kuczkowski, D. Schuchmann, U. Flörke and M. Nieger, Organometallics, 2006, 25, 5487.

15 C. Ganesamoorthy, D. Bläser, C. Wölper and S. Schulz, Organometallics, 2015, 34, 2991.

16 C. Ganesamoorthy, D. Bläser, C. Wölper and S. Schulz, Chem. Commun., 2014, 50, 12382.

17 L. Tuscher, C. Ganesamoorthy, D. Bläser, C. Wölper and S. Schulz, Angew. Chem., 2015, 127, 10803, (Angew. Chem., Int. Ed., 2015, 54, 10657).

18 C. Ganesamoorthy, D. Bläser, C. Wölper and S. Schulz, Angew. Chem., 2014, 126, 11771, (Angew. Chem., Int. Ed., 2014, 53, 11587).

19 C. Ganesamoorthy, G. Bendt, D. Bläser, C. Wölper and S. Schulz, Dalton Trans., 2015, 44, 5153.

20 J. D. Gorden, C. L. B. Macdonald and A. H. Cowley, Main Group Chem., 2005, 4, 33.

21 C. Schenk, R. Köppe, H. Schnöckel and A. Schnepf, Eur. J. Inorg. Chem., 2011, 3681.

22 H. V. R. Dias and W. Jin, Inorg. Chem., 2000, 39, 815.

23 M. C. Kuchta, J. B. Bonanno and G. Parkin, J. Am. Chem. Soc., 1996, 118, 10914.

24 K. Yurkerwich, D. Buccella, J. G. Melnick and G. Parkin, Chem. Sci., 2010, 1, 210.

25 P. Jutzi, B. Neumann, G. Reumann, L. O. Schebaum and H.-G. Stammler, Organometallics, 2001, 20, 2854.

26 K. Yurkerwich and G. Parkin, J. Cluster Sci., 2010, 21, 225.

27 P. Pyykkö and M. Atsumi, Chem. - Eur. J., 2009, 15, 186.

28 (a) C. E. Radzewich, M. P. Coles and R. F. Jordan, J. Am. Chem. Soc., 1998, 120, 9384; (b) T. E. Stennett, J. Pahl, H. S. Zijlstra, F. W. Seidel and S. Harder, Organometallics, 2016, 35, 207. 
29 S. Gondzik, D. Bläser, C. Wölper and S. Schulz, J. Organomet. Chem., 2015, 783, 92.

30 S. Lancaster, Chem. Spider Synthetic Pages, 2013, DOI: 10.1039/SP215, http://cssp.chemspider.com/215.

31 (a) S. Feng, G. R. Roof and E. Y.-X. Chen, Organometallics, 2002, 21, 832; (b) J. Chen and E. Y.-X. Chen, Dalton Trans., 2016, 45, 6105.

32 K. Ludovici, W. Tyrra and D. Naumann, J. Organomet. Chem., 1992, 441, 363.
33 G. M. Sheldrick, Acta Crystallogr., Sect. A: Fundam. Crystallogr., 1990, 46, 467.

34 G. M. Sheldrick, SHELXL-2014, Program for the Refinement of Crystal Structures, University of Göttingen, Göttingen, Germany, 2014. See also: G. M. Sheldrick, Acta Crystallogr., Sect. A: Fundam. Crystallogr., 2008, 64, 112, shelXle, A Qt GUI for SHELXL. C. B. Hübschle, G. M. Sheldrick and B. Dittrich, J. Appl. Crystallogr., 2011, 44, 1281. 